\title{
Germination and Seedling Growth of Desmanthus illinoensis and Desmodium canadense in Response to Mechanical Scarification
}

\author{
Michael W. Olszewski ${ }^{1}$ and Courtney A. Young \\ Temple University, Department of Landscape Architecture and Horticulture, \\ School of Environmental Design, 580 Meetinghouse Road, Ambler, \\ PA 19002

\section{Joel B. Sheffield} \\ Temple University, Department of Biology, College of Science and \\ Technology, 1900 North 12th Street, Philadelphia, PA 19122
}

Additional index words. Illinois bundleflower, showy ticktrefoil, warm-season legume, native plants, ecological restoration, electric seed scarifier

\begin{abstract}
Illinois bundleflower [Desmanthus illinoensis (Michx.) MacMill. ex B.L. Rob. \& Fernald] and showy ticktrefoil [Desmodium canadense (L.) DC.] are legumes native to North America used during meadow restoration efforts. However, insufficient or slow germination or reduced emergence may result attributable to seedcoat-mediated reductions in permeability to water. The objective of this research was to determine the effectiveness of a single-speed electric scarifier lined with 40-grit sandpaper for increasing germination and seedling growth of two native legumes. Seeds of Illinois bundleflower and showy ticktrefoil were mechanically scarified for 3, 6, or $12 \mathrm{~s}$ before they were subjected to germination and vigor testing. After scarification, final germination percentage (FGP), germination rate, and uniformity at multiple temperatures (15, 20, and/or 20 to $30^{\circ} \mathrm{C}$ ) were improved for Illinois bundleflower. However, FGP decreased for showy ticktrefoil, whereas germination rate and uniformity increased. For both species, there was a decline in FGP with longer scarification durations. Illinois bundleflower seed subjected to scarification and accelerated aging (AA) had higher FGP than non-scarified seed subjected to AA (59\% and 6\%, respectively), whereas both scarified and non-scarified seed of showy ticktrefoil subjected to AA had low FGP (11\% and $18 \%$, respectively). Mechanical scarification increased electrical conductivity (EC) of leachates for both species, but scarified showy ticktrefoil seed subjected to AA resulted in the highest EC compared with all other treatments, indicating a reduction of vigor. Evaluation of a seedling grow-out test 3 weeks after sowing confirmed that emergence was enhanced after $3 \mathrm{~s}$ of mechanical scarification of Illinois bundleflower seed but that scarification of showy ticktrefoil seed decreased emergence and increased the number of abnormal seedlings. Mechanical scarification resulted in peripheral damage and seed tissue obliteration of both species as indicated by viewing with a stereomicroscope. We conclude that scarifier limitations caused excessive physical damage of showy ticktrefoil. For Illinois bundleflower, however, mechanical scarification using an electric scarifier increased emergence from $18 \%$ (non-scarified seed) to $77 \%$ after $3 \mathrm{~s}$ of scarification and FGP from $32 \%$ (non-scarified seed) to $87 \%$ after 3 s of scarification. Compared with responses from non-scarified Illinois bundleflower seeds, scarification treatment also resulted in $24 \%$ faster germination and $37 \%$ more uniformity.
\end{abstract}

Illinois bundleflower and showy ticktrefoil are perennial warm-season legumes native to the United States found in prairies, woodland

\footnotetext{
Received for publication 3 May 2010. Accepted for publication 28 July 2010.

Funding for this research was provided by a grant from Temple University's Office of the Provost Seed Grant Program.

Mention of a trademark, proprietary product, or vender does not constitute a guarantee of the product by Temple University and does not imply its approval to the exclusion of other products or venders that also may be suitable.

${ }^{1}$ To whom reprint requests should be addressed; e-mail olszewsk@temple.edu.
}

edges, wet meadows, or disturbed areas in 30 and 28 states, respectively (USDA, NRCS, 2010a). Stands of Illinois bundleflower or other legumes grown with switchgrass (Panicum virgatum L.), sideoats grama [Bouteloua curtipendula (Michx.) Torr.], or Indiangrass [Sorghastrum nutans (L.) Nash] had higher forage yield than if grass stands were grown without legumes (Posler et al., 1993). Both Illinois bundleflower and showy ticktrefoil are used for range revegetation or prairie restoration (USDA, NRCS, 2010a), but plant competition has a significant impact on Illinois bundleflower and other native legume stands (Beran et al., 1999, 2000; Dovel et al., 1990). The cultivar Sabine Illinois bundleflower is used in reclaimed mine areas, rangeland, or pastures, providing ecological benefit to areas of Texas worth almost \$225,000 (USDA, NRCS, 2010b).

Pea (Pisum sativum L.) seedcoats prevent rapid imbibition, which may damage the embryo (Powell and Matthews, 1978). However, the seedcoat may be multifunctional and can limit electrolyte leakage and subsequent growth of facultative plant pathogenic fungi; water-impermeable "hard" seedcoats are common in many legumes, serve a protective function for the embryo, and have been the subject of several reviews (Baskin, 2003; Kelly et al., 1992; Mohamed-Yasseen et al., 1994; Rolston, 1978). Latting (1961) determined that mechanical scarification of Illinois bundleflower seed resulted in higher final germination percentage (FGP) compared with sulfuric acid scarification, alternate freezing and thawing, hot water, or control treatments. Mean germination time of 3- or 4-year-stored Illinois bundleflower seed decreased when acid or mechanical scarification was used (Call, 1985). Mechanical scarification of prostrate bundleflower [Desmanthus virgatus (L.) Willd. var. depressus (Humb. \& Bonpl. ex Willd.) Turner] seed resulted in higher FGP at a variety of temperatures (Fulbright and Flenniken, 1987).

Dormancy of Illinois bundleflower is the result of a hard seedcoat and abrasion of individual seed with a razor blade or knife is more effective than sulfuric acid soaks at achieving high FGP (Call, 1985; Latting, 1961). There are few publications regarding scarification of showy ticktrefoil seed, although concentrated sulphuric acid soaks are recommended to break dormancy of D. intortum (Mill.) Urb. and D. uncinatum (Jacq.) DC. (ISTA, 2010). General recommendations suggest scarification of Illinois bundleflower and showy ticktrefoil seed before field sowing (USDA, NRCS, 2010a).

Scarifiers have been used to alleviate dormancy in Ruby Valley pointvetch (Oxytropis riparia Litv.; Hicks et al., 1989) and mastic tree (Pistacia lentiscus L.; Piotto, 1995). Varying scarification durations of 5 to $30 \mathrm{~s}$ were required for different seed lots of Ruby Valley pointvetch, a legume, for optimum germination (Hicks et al., 1989). Scarifier (Forsberg, Thief River Falls, MN) equipment is simple to operate and consists of a horizontally mounted rotary propeller within a steel drum lined with 40-grit sandpaper (Liu, 2007). Although mechanical abrasion by using the scarifier is a low-cost method with good repeatability, there is a lack of methodological standardization, including running time, seed moisture content, amount of surface damage, and reference materials (Liu, 2008). Mechanical scarification using a scarifier is a more practical method of scarification than other techniques (Hicks et al., 1989).

Vigor tests are more accurate in determining field crop performance of a seed lot than standard germination tests and their use has increased as a result of consumer demand (Ferguson, 1993). Vigor is a concern to growers because a loss of vigor may indicate a reduction in field performance (Copeland and McDonald, 
2001). Contemporary standards use electrical conductivity (EC) and accelerated aging for determining seed vigor (ISTA, 2010); however, seed companies use a variety of vigor-testing methods (Copeland and McDonald, 2001). Imbibitional damage of pea cotyledons resulted in higher EC of leachate when the seedcoat was removed, indicating a relationship between "intactness" of the seedcoat and embryo health (Powell and Matthews, 1978). In studies involving soybean [Glycine max (L.) Merr.], germination percentage of seed subjected to accelerated aging procedures was used to determine seed vigor (Baskin, 1977).

At present, there is no established, rapid mechanical seed scarification method for native legumes such as Illinois bundleflower or showy ticktrefoil. The objective of this study was to determine the influence of mechanical scarification using a Forsberg sandpaperlined electric scarifier on seed germination and vigor of Illinois bundleflower and showy ticktrefoil.

\section{Materials and Methods}

Single seed lots of 'NE Ecotype' Illinois bundleflower and 'PA Ecotype' showy ticktrefoil were obtained from Ernst Conservation Seeds (Meadville, PA) and used for the following experiments. For both seed lots, there was no labeled dormancy. After purchase of seed lots, seeds were stored in plastic bags under cool and dry conditions $\left(7^{\circ} \mathrm{C}\right.$ and $32 \%$ relative humidity) for 5 months before the start of experiments.

Seeds were subjected to scarification by placing $1.0 \mathrm{~g}$ seed on 40-grit sandpaper within a Model 6K030G scarifier (Forsberg, Thief River Falls, MN) that was turned on for 3, 6, or $12 \mathrm{~s}$. Materials and general operating procedures for the scarifier (Forsberg) were described by Liu (2007). It consists of a $2300-\mathrm{cm}^{3}$ capacity stationary drum lined with sandpaper fitted into a cylinder with a rotating propeller. After scarification, seed were placed onto two layers of germination No. 385 blotters (Seedburo Co., Chicago, IL) moistened with $20 \mathrm{~mL}$ distilled water contained in $125 \times 80 \times$ 20-mm transparent polystyrene boxes with tight-fitting lids and incubated at 15,20 , or 20 to $30{ }^{\circ} \mathrm{C}$ (16 to $\left.8 \mathrm{~h}\right)$ in darkness. Nonscarified seed were included as a control. Suggested testing temperature for Illinois bundleflower is alternating 20 to $30{ }^{\circ} \mathrm{C}$ (AOSA, 2007a). Germination rules for showy ticktrefoil have not yet been determined, but the suggested temperature for $D$. uncinatum and $D$. intortum is 20 to $30{ }^{\circ} \mathrm{C}$ (ISTA, 2010). The number of seeds germinated (those having a visible radicle) were counted daily and removed.

Scarified seed were subjected to an accelerated aging test using basic principles described by Baskin (1977). The accelerated aging test is a rapid, simple determination of vigor that can be applied to many plant species (Copeland and McDonald, 2001). Seeds (5 g) were contained in a metal cylinder and placed into a lidded plastic box holding $250 \mathrm{~mL}$ of distilled water. The chamber was maintained at $41{ }^{\circ} \mathrm{C}$ for $72 \mathrm{~h}$ at nearly $100 \%$ relative humidity. Seed moisture content was calculated before and after experiments by using a high-temperature drying method $\left(130{ }^{\circ} \mathrm{C}\right.$ for $1 \mathrm{~h}$ ) and two replications with results expressed as the percentage weight of water lost from the initial seed weight (ISTA, 2010).

Procedures for EC testing were conducted by following methods from Hampton and TeKrony (1995) and modified by Wang et al. (2004) for small seeds. Seeds (5 g) were weighed, placed into $100 \mathrm{~mL}$ distilled water (water purity less than $5 \mu \mathrm{S} \cdot \mathrm{cm}^{-1}$ ), and incubated at $20{ }^{\circ} \mathrm{C}$ in darkness for $24 \mathrm{~h}$. Hard seed then were removed, blotted dry, and weighed. Hard seed were not subtracted from the initial seed weight before final calculations because subsequent incubation tests determined they were slowly imbibing and capable of leaking electrolytes. EC was measured using an EC Testr11 plus meter (Oakton Instruments, Vernon Hills, IL) and results were expressed as $\mu \mathrm{S} \cdot \mathrm{cm}^{-1} \cdot \mathrm{g}^{-1}$.

Seedling grow-out tests may be used to distinguish between strong and weak seedlings within a seed lot (Hartmann et al., 2002). The seedling grow-out test was performed using the following procedure. Redi-Earth Plug and Seedling peat-based substrate (SunGro Horticulture, Bellevue, WA) was placed into 20$\mathrm{mm}$-width $\times 37$-mm-depth plugs, irrigated, and one scarified or non-scarified seed was sown per plug. Plugs were misted and a clear plastic dome was placed on top to prevent moisture loss. The growth chamber was set at 20 to $30{ }^{\circ} \mathrm{C}$ [14 to $10 \mathrm{~h}$; dark-light $\left.\left(71 \mu \mathrm{mol} \cdot \mathrm{m}^{-2} \cdot \mathrm{s}^{-1}\right)\right]$. Emergence (having a visible hypocotyl) was recorded daily. Abnormal seedlings were counted as those not possessing essential structures required to produce a healthy, mature plant (AOSA, 2007b). After 3 weeks of seedling growth, plants were cut at the substrate surface and seedling dry weight determined (oven drying at $80^{\circ} \mathrm{C}$ for $24 \mathrm{~h}$ ).

Damage caused by scarification was determined by viewing through a dissecting microscope. Seeds were subjected to scarification using the procedure previously described. Images were captured using a fiberoptic illuminator and a Nikon Coolpix 8700 digital camera (Tokyo, Japan).

All seed germination experiments were arranged in a randomized complete block design with four replications per treatment. Experiments for determination of EC were arranged randomly with three replications per treatment. From these germination counts, the angular transformation $[\arcsin \sqrt{ } \%$ transformation in degrees (deg.)] of FGP or final emergence percentage (FEP), days to $50 \%$ FGP $\left(\mathrm{G}_{50}\right.$, an inverse measure of germination rate), days between $10 \%$ and $90 \%$ FGP $\left(\mathrm{G}_{10-90}\right.$, a measure of germination uniformity), and square root transformation of abnormal seedling percentage were subjected to analysis of variance using PROC GLM (SAS 9.1; SAS Institute, Inc., Cary, NC). Percentage data transformations were followed as per Gomez and Gomez (1984). Time to $10 \%, 50 \%$, and
$90 \%$ germination was based on a mathematical formula (Olszewski et al., 2009):

$$
\begin{aligned}
\mathrm{G}_{\mathrm{x}}= & \mathrm{N}+\left\{\left[(\mathrm{Y} \times \mathrm{TSG})-\mathrm{SG}_{\mathrm{N}}\right] /\right. \\
& \left.\left(\mathrm{SG}_{\mathrm{N}+1}-\mathrm{SG}_{\mathrm{N}}\right)\right\}
\end{aligned}
$$

where $G_{x}$ is $G_{10} G_{50}$, or $G_{90} ; N$ equals the number of the last day after initiation of the germination assay with less than $10 \%, 50 \%$, or $90 \%$ of final germination, respectively, for $G_{10}, G_{50}$, or $G_{90}$; Y equals $0.1,0.5$, or 0.9 , respectively, for $\mathrm{G}_{10}, \mathrm{G}_{50}$, or $\mathrm{G}_{90}$; TSG equals total number of seeds germinated; $\mathrm{SG}_{\mathrm{N}}$ equals the number of seed germinated by day $\mathrm{N}$; and $\mathrm{SG}_{\mathrm{N}+1}$ equals the number of seeds germinated by day $\mathrm{N}+1$. Germination uniformity was calculated using the equation $\mathrm{G}_{10-90}=\left(\mathrm{G}_{90}-\mathrm{G}_{10}\right)$.

\section{Results}

Germination rates of Illinois bundleflower and showy ticktrefoil increased (lower $\mathrm{G}_{50}$ values) with longer scarification duration and/or higher germination temperature (Tables 1 and 2). Among those seeds receiving mechanical scarification, treatment for $12 \mathrm{~s}$ resulted in the lowest FGP for Illinois bundleflower and showy ticktrefoil (FGP for three germination temperatures $=76 \%$ and $4 \%$, respectively). Scarification duration of Illinois bundleflower seed had a greater effect on FGP at 20 to $30^{\circ} \mathrm{C}$ than at 15 or $20^{\circ} \mathrm{C}$. Nonscarified Illinois bundleflower seed had $28 \%$, $30 \%$, and $38 \% \mathrm{FGP}$ at germination temperatures of 15,20 , or 20 to $30{ }^{\circ} \mathrm{C}(16$ to $8 \mathrm{~h})$ in darkness, respectively, but after scarification ( $3 \mathrm{~s}$ in a scarifier) had $85 \%, 83 \%$, and $92 \%$ FGP. As scarification duration increased, showy ticktrefoil FGP decreased; however, seed at any scarification duration performed similarly regardless of germination temperature. Overall, Illinois bundleflower and showy ticktrefoil had lower $\mathrm{G}_{10-90}$ values at 20 to $30{ }^{\circ} \mathrm{C}$ than at 15 or $20{ }^{\circ} \mathrm{C}$. Whereas Illinois bundleflower had a minimal difference between $\mathrm{G}_{10-90}$ values for the three scarification durations at each germination temperature, a 12-s scarification duration resulted in lowest $\mathrm{G}_{10-90}$ values for showy ticktrefoil.

Scarified and non-scarified seeds of Illinois bundleflower or showy ticktrefoil subjected to accelerated aging (AA) resulted in decreased FGP (Table 3). Scarified Illinois bundleflower seed subjected to AA had 59\% FGP, whereas non-scarified seed subjected to AA had 6\% FGP. After AA, scarified showy ticktrefoil seed had FGP of $11 \%$ and nonscarified seed had an FGP of $18 \%$, whereas non-scarified and scarified seed without AA had $78 \%$ and $58 \%$ FGP, respectively. Seed moisture contents of non-scarified (control) Illinois bundleflower and showy ticktrefoil seed were $6.0 \% \pm 0.1 \%$ and $7.0 \% \pm 0.4 \%$, respectively. After AA, non-scarified seed attained moisture contents of $13.7 \% \pm 0.4 \%$ and $13.3 \% \pm 0.4 \%$, whereas scarified seed attained moisture contents of $15.7 \% \pm 0.1 \%$ and $14.7 \% \pm 0.2 \%$ for Illinois bundleflower and showy ticktrefoil, respectively. Nonscarified Illinois bundleflower seed subjected 
Table 1. Final germination percentage (FGP) and its angular transformation (deg.), days to $50 \%$ of FGP $\left(\mathrm{G}_{50}\right)$, and days between $10 \%$ and $90 \%$ of FGP $\left(\mathrm{G}_{10-90}\right)$ of Illinois bundleflower after mechanical seed scarification and incubation at three temperature regimes.

\begin{tabular}{|c|c|c|c|c|}
\hline Scarification duration $(\mathrm{s})^{\mathrm{z}}$ & Germination temp $\left({ }^{\circ} \mathrm{C}\right)^{\mathrm{y}}$ & FGP \% (deg.) & $\mathrm{G}_{50}$ (days) & $\mathrm{G}_{10-90}$ (days) \\
\hline \multirow[t]{3}{*}{0 (control) } & 15 & $28(31)$ & 4.2 & 5.8 \\
\hline & 20 & $30(33)$ & 2.5 & 3.9 \\
\hline & $20-30$ & $38(38)$ & 1.9 & 3.2 \\
\hline \multirow[t]{3}{*}{3} & 15 & $85(68)$ & 4.2 & 4.3 \\
\hline & 20 & $83(65)$ & 1.4 & 2.0 \\
\hline & $20-30^{y}$ & $92(74)$ & 1.1 & 1.8 \\
\hline \multirow[t]{3}{*}{6} & 15 & $83(66)$ & 3.3 & 3.4 \\
\hline & 20 & $83(65)$ & 1.4 & 2.3 \\
\hline & $20-30^{y}$ & $91(72)$ & 1.5 & 1.7 \\
\hline \multirow[t]{3}{*}{12} & 15 & $70(57)$ & 3.6 & 3.9 \\
\hline & 20 & $78(62)$ & 1.5 & 2.2 \\
\hline & $20-30^{y}$ & $79(64)$ & 1.2 & 2.2 \\
\hline $\operatorname{LSD}_{0.05^{\mathrm{x}}}$ & & (10) & 0.7 & 2.1 \\
\hline \multicolumn{5}{|l|}{ Significance } \\
\hline Scarification duration (SD) & & $* * *$ & $* * *$ & * \\
\hline SD-linear & & $* * *$ & NS & * \\
\hline SD-quadratic & & $* * *$ & NS & NS \\
\hline $\begin{array}{l}\text { Germination temperature } \\
\text { (GT) }\end{array}$ & & $* *$ & $* * *$ & $* * *$ \\
\hline $\mathrm{SD} \times \mathrm{GT}$ & & NS & $*$ & NS \\
\hline
\end{tabular}

${ }^{\text {z} S e e d s ~ w e r e ~ s u b j e c t e d ~ t o ~ s c a r i f i c a t i o n ~ b y ~ p l a c i n g ~} 1.0 \mathrm{~g}$ seed on 40 -grit sandpaper within an electric scarifier for specified durations.

${ }^{y}$ All seeds were incubated in darkness. Seed incubated at 20 to $30{ }^{\circ} \mathrm{C}$ included a 16 -h incubation period at $20{ }^{\circ} \mathrm{C}$ and an 8 -h incubation period at $30{ }^{\circ} \mathrm{C}$.

${ }^{\mathrm{x}} \mathrm{LSD}_{0.05}=$ Fisher's protected least significant difference.

NS, $* * *, * * *$ Nonsignificant or significant at $P \leq 0.05, P \leq 0.01$, or $P \leq 0.001$, respectively.

deg. $=$ angular transformation of mean.

Table 2. Final germination percentage (FGP) and its angular transformation (deg.), days to $50 \%$ of FGP $\left(\mathrm{G}_{50}\right)$, and days between $10 \%$ and $90 \%$ of FGP $\left(\mathrm{G}_{10-90}\right)$ of showy ticktrefoil after mechanical seed scarification and incubation at three temperature regimes.

\begin{tabular}{|c|c|c|c|c|}
\hline Scarification duration $(\mathrm{s})^{\mathrm{z}}$ & Germination temp $\left({ }^{\circ} \mathrm{C}\right)^{\mathrm{y}}$ & FGP \% (deg.) & $\mathrm{G}_{50}$ (days) & $\mathrm{G}_{10-90}$ (days) \\
\hline \multirow[t]{3}{*}{0 (control) } & 15 & $76(61)$ & 12.5 & 6.6 \\
\hline & 20 & $81(64)$ & 9.1 & 5.4 \\
\hline & $20-30$ & $79(67)$ & 8.0 & 5.3 \\
\hline \multirow[t]{3}{*}{3} & 15 & $66(54)$ & 4.5 & 4.7 \\
\hline & 20 & $61(51)$ & 2.8 & 2.9 \\
\hline & $20-30^{y}$ & $72(58)$ & 2.4 & 2.4 \\
\hline \multirow[t]{3}{*}{6} & 15 & $43(40)$ & 4.2 & 6.4 \\
\hline & 20 & $51(46)$ & 2.5 & 4.6 \\
\hline & $20-30^{y}$ & $58(49)$ & 2.4 & 2.2 \\
\hline \multirow[t]{3}{*}{12} & 15 & $2(6)$ & 5.0 & 0.8 \\
\hline & 20 & $4(9)$ & 2.5 & 1.4 \\
\hline & $20-30^{y}$ & $5(12)$ & 2.1 & 1.1 \\
\hline $\operatorname{LSD}_{0.05^{\mathrm{x}}}$ & & (11) & 3.2 & 2.4 \\
\hline \multicolumn{5}{|l|}{ Significance } \\
\hline Scarification duration (SD) & & $* * *$ & $* * *$ & $* * *$ \\
\hline $\mathrm{SD}$-linear & & $* * *$ & $* * *$ & $* * *$ \\
\hline SD-quadratic & & $* * *$ & $* * *$ & NS \\
\hline $\begin{array}{l}\text { Germination temperature } \\
\text { (GT) }\end{array}$ & & NS & $* *$ & $*$ \\
\hline $\mathrm{SD} \times \mathrm{GT}$ & & NS & NS & NS \\
\hline
\end{tabular}

${ }^{\mathrm{z} S e e d s}$ were subjected to scarification by placing $1.0 \mathrm{~g}$ seed on 40 -grit sandpaper within an electric scarifier for specified durations.

${ }^{y}$ All seeds were incubated in darkness. Seed incubated at 20 to $30{ }^{\circ} \mathrm{C}$ included a $16-\mathrm{h}$ incubation period at $20{ }^{\circ} \mathrm{C}$ and an 8 -h incubation period at $30{ }^{\circ} \mathrm{C}$.

${ }^{\mathrm{LSD}_{0.05}}=$ Fisher's protected least significant difference

NS, *,**,***Nonsignificant or significant at $P \leq 0.05, P \leq 0.01$, or $P \leq 0.001$, respectively.

deg. $=$ angular transformation of mean

to AA had higher $\mathrm{G}_{50}$ and $\mathrm{G}_{10-90}$ values compared with other treatments. Compared with an untreated control, there was no effect on $\mathrm{G}_{50}$ for Illinois bundleflower seed that was scarified and subjected to AA.

Scarified seed leachate had higher EC values than non-scarified (control) seeds (Fig. 1). Non-scarified (control) seed of showy ticktrefoil and Illinois bundleflower had the lowest EC values (13 and $44 \mu \mathrm{S} \cdot \mathrm{cm}^{-1} \cdot \mathrm{g}^{-1}$, respectively). After AA of non-scarified seed, for non-scarified seed (Table 4). There were no differences between abnormal seedling counts for scarified or non-scarified Illinois bundleflower; however, scarified showy ticktrefoil seed had a higher percentage of abnormal seedlings $(16 \%)$ than did non-scarified seed $(1 \%)$. There were no seedling dry weight differences for scarified or non-scarified Illinois bundleflower or showy ticktrefoil.

A specialized U-shaped depression within the seedcoat, called the pleurogram, is located on Illinois bundleflower (Fig. 2A), whereas a conspicuous oval-shaped, slightly raised hilum is located on showy ticktrefoil (Fig. 2B). After $3 \mathrm{~s}$ of mechanical scarification, the seedcoat was abraded along the periphery of the seed and, sometimes, damage penetrated into the cotyledonary tissue (Fig. 2C-D). Damage was similar for Illinois bundleflower and showy ticktrefoil with regard to the peripheral damage of the seedcoat. Occasionally, seed had severe tissue obliterations after $3 \mathrm{~s}$ of mechanical scarification. No damage to the hilum or the pleurogram was observed after $3 \mathrm{~s}$ in a scarifier. Increasing the duration of scarification increased the amount of peripheral damage and the amount of seed tissue obliteration.

\section{Discussion}

Germination and vigor tests of mechanically scarified Illinois bundleflower seed indicated that FGP, $\mathrm{G}_{50}$, and FEP can be improved after a 3-s scarification procedure (Tables 1 and 4). Additionally, we found benefits at suboptimal germination temperatures. Seedcoat damage was moderate, but sometimes relatively large obliterations occurred around the periphery of the seed (Fig. 2C). Increasing the scarification duration increases the amount of obliteration; thus, for successful scarification, the amount of damage requires visual monitoring as well as germination and vigor testing. Mechanical scarification using a scarifier has direct commercial applications for increasing stand establishment (Hicks et al., 1989). Results from seeding of Illinois bundleflower in the field indicated that subsequent stands can vary widely by year and that initial, rapid plant establishment is important (Dovel et al., 1990). Compared with "nicking" techniques with razor blades or knives and sulphuric acid soaks that increased germination percentage of Illinois bundleflower (Call, 1985; Latting, 1961), the use of a scarifier is a practical method of scarification.

Although uniform repeatability was associated with the Forsberg scarifier (Liu, 2008), we found FGP variation at incubation temperatures of 20 to $30{ }^{\circ} \mathrm{C}$ after a 3-s scarification treatment in which Illinois bundleflower had $92 \%$ or $80 \%$ FGP and showy ticktrefoil had $72 \%$ or $58 \%$ FGP (Tables $1-3$ ). Nonetheless, IL bundleflower seed benefited from a short scarification procedure. Non-scarified showy ticktrefoil was slow-germinating, but most seed emerged by the third week after sowing (Table 4). Scarification damaged the showy ticktrefoil embryo as indicated by the higher number of abnormal seedlings and, 
Table 3. Final germination percentage (FGP) and its angular transformation (deg.), days to $50 \%$ of FGP $\left(\mathrm{G}_{50}\right)$, and days between $10 \%$ and $90 \%$ of FGP ( $\left.\mathrm{G}_{10-90}\right)$ of Illinois bundleflower and showy ticktrefoil after mechanical seed scarification and accelerated aging. ${ }^{.}$

\begin{tabular}{|c|c|c|c|c|c|c|c|c|c|}
\hline \multirow{2}{*}{\multicolumn{2}{|c|}{ Seed treatments }} & \multicolumn{8}{|c|}{ Legume Species } \\
\hline & & \multicolumn{4}{|c|}{ Illinois bundleflower } & \multicolumn{4}{|c|}{ Showy ticktrefoil } \\
\hline No & Yes & $7.0 \pm 0.1$ & $80(64)$ & 1.4 & 1.4 & $6.7 \pm 0.1$ & $58(49)$ & 2.7 & 6.2 \\
\hline Yes & No & $13.7 \pm 0.4$ & $6(13)$ & 2.8 & 4.5 & $13.3 \pm 0.4$ & $18(25)$ & 5.9 & 7.6 \\
\hline Yes & Yes & $15.7 \pm 0.1$ & $59(50)$ & 1.5 & 1.6 & $14.7 \pm 0.2$ & $11(19)$ & 7.2 & 5.0 \\
\hline $\operatorname{LSD}_{0.05}{ }^{\mathrm{v}}$ & & & (9) & 0.6 & 2.1 & & (7) & 3.0 & 4.9 \\
\hline
\end{tabular}

${ }^{\mathrm{z}} \mathrm{All}$ seeds were incubated at 20 to $30^{\circ} \mathrm{C}$ using a 16-h incubation period at $20^{\circ} \mathrm{C}$ in darkness and an 8 -h incubation period at $30{ }^{\circ} \mathrm{C}$ in darkness.

${ }^{y}$ Seeds were subjected to accelerated aging by incubating $5 \mathrm{~g}$ seed at $41{ }^{\circ} \mathrm{C}$ for $72 \mathrm{~h}$ in nearly $100 \%$ relative humidity before seed testing.

${ }^{x}$ Seeds were subjected to scarification by placing $1.0 \mathrm{~g}$ seed on 40 -grit sandpaper within an electric scarifier for $3 \mathrm{~s}$.

${ }^{w}$ Seed moisture percentage $( \pm \mathrm{SD})$ was based on water loss $\left(130^{\circ} \mathrm{C}\right.$ for $\left.1 \mathrm{~h}\right)$ from initial seed weight and two replicates.

${ }^{\mathrm{v}} \mathrm{LSD}_{0.05}=$ Fisher's protected least significant difference.

deg. = angular transformation of mean.

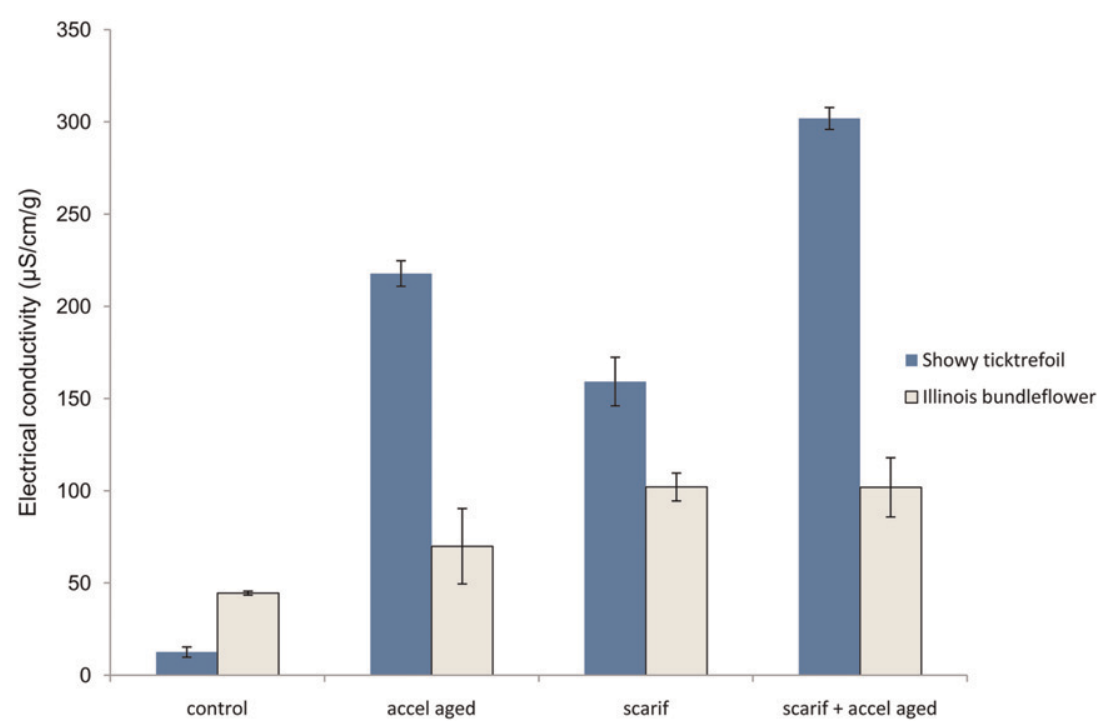

Fig. 1. Electrical conductivity (EC) measurements of showy ticktrefoil and Illinois bundleflower seed subjected to accelerated aging (accel aged), scarification (scarif), or scarification followed by accelerated aging (scarif + accel aged). Non-scarified seed without accelerated aging were used as the control. Incubation of $5 \mathrm{~g}$ seed in distilled water for $\mathrm{EC}$ measurements was at $20^{\circ} \mathrm{C}$ in darkness for $24 \mathrm{~h}$ and, for accelerated aging, by adding $5 \mathrm{~g}$ seed at $41^{\circ} \mathrm{C}$ for $72 \mathrm{~h}$ at $\approx 100 \%$ relative humidity. Error bars $=$ SD.

Table 4. Final emergence percentage (FEP) and its angular transformation (deg.), abnormal seedling percentage (ASP) and its square root transformation $(\sqrt{ })$, and seedling dry weight of Illinois bundleflower and showy ticktrefoil after mechanical scarification and sowing into peat-based substrate and subsequent incubation at 20 to $30^{\circ} \mathrm{C}$ (14 to $10 \mathrm{~h}$; dark-light) for 3 weeks.

\begin{tabular}{|c|c|c|c|c|c|c|}
\hline \multirow[b]{3}{*}{ Scarification $^{z}$} & \multicolumn{6}{|c|}{ Legume species } \\
\hline & \multicolumn{3}{|c|}{ Illinois bundleflower } & \multicolumn{3}{|c|}{ Showy ticktrefoil } \\
\hline & $\begin{array}{l}\text { FEP \% } \\
\text { (deg.) }\end{array}$ & $\begin{array}{c}\text { ASPy }^{\text {y }} \% \\
(\sqrt{ })\end{array}$ & $\begin{array}{c}\text { Dry wt }{ }^{\mathrm{x}} \\
\text { (mg/shoot) }\end{array}$ & $\begin{array}{l}\text { FEP \% } \\
\text { (deg.) }\end{array}$ & $\begin{array}{c}\text { ASPy }^{\text {y }} \% \\
(\sqrt{ })\end{array}$ & $\begin{array}{c}\text { Dry wt }^{\mathrm{x}} \\
\text { (mg/shoot) }\end{array}$ \\
\hline No & $18(25)$ & $3(2)$ & 5.3 & $74(59)$ & $1(1)$ & 3.8 \\
\hline Yes & $77(61)$ & $4(2)$ & 6.5 & $15(22)$ & $16(4)$ & 4.7 \\
\hline $\operatorname{LSD}_{0.05}{ }^{\mathrm{w}}$ & $(8)$ & (1) & 2.1 & (12) & (1) & 1.0 \\
\hline
\end{tabular}

${ }^{\mathrm{z}}$ Seeds were subjected to scarification by placing $1.0 \mathrm{~g}$ seed on 40 -grit sandpaper within an electric scarifier for $3 \mathrm{~s}$.

${ }^{y}$ Abnormal seedlings were those that did not contain essential structures for healthy development into a mature plant.

${ }^{\mathrm{x}}$ After 3 weeks, seedlings were cut at the substrate surface and oven-dried at $80{ }^{\circ} \mathrm{C}$ for $24 \mathrm{~h}$ to determine seedling dry weight.

${ }^{\mathrm{w}_{\mathrm{LSD}}} \mathrm{D}_{05}=$ Fisher's protected least significant difference.

deg. = angular transformation of mean.

$\sqrt{ }=$ square root transformation of mean.

although emergence is high without scarification, the slow rate of germination may limit stand establishment. A brief report indicated that hand scarification of showy ticktrefoil

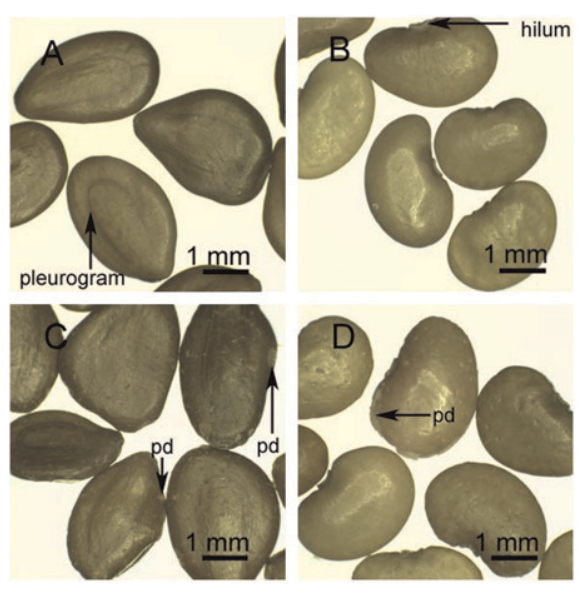

Fig. 2. Seeds of (A) non-scarified Illinois bundleflower; (B) non-scarified showy ticktrefoil; (C) scarified Illinois bundleflower; and (D) scarified showy ticktrefoil. Seeds were scarified in an electric scarifier for $3 \mathrm{~s}$. The U-shaped pleurogram of Illinois bundleflower and the hilum of showy ticktrefoil are shown. Arrows indicate peripheral damage (pd) caused by the scarification process.

sandpaper (including brief abrasion of the region of the hilum) and subsequent incubation at 20 to $30{ }^{\circ} \mathrm{C}$ resulted in a $1 \%$ increase in $\mathrm{FGP}$, a $64 \%$ increase in germination rate, and a $29 \%$ increase in germination uniformity (data not shown).

Higher degrees of seedcoat damage caused by scarification of Chinese licorice (Glycyrrhiza uralensis Fisch. ex DC.) resulted in increasingly higher EC values of leachate (Jin et al., 2006). In pea (Pisum sativum L.), increased cracking of the seedcoat resulted in increased electrolyte leakage and low seed vigor (Powell and Matthews, 1979). Our results confirm a similar phenomenon whereby mechanical scarification resulted in increased EC of Illinois bundleflower and showy ticktrefoil (Fig. 1). However, there was no difference in EC between non-scarified and scarified Illinois bundleflower seed subjected to AA, indicating that scarification did not reduce vigor. Higher EC values of showy ticktrefoil seed subjected to scarification followed by AA indicated that scarification lowered vigor.

Use of a scarifier could potentially aid restoration ecologists to rapidly break physical dormancy of native legumes before sowing or 
to enhance uniformity of native plug production in greenhouses. Mechanical scarification using a Forsberg seed scarifier is a more successful and feasible commercial method than acid scarification of Ruby Valley Pointvetch, a legume (Hicks et al., 1989); however, equipment specifications of motor size (one speed) and single-sized form-fitting sandpaper liner (40 grit) limit the use of this instrument for native legumes. A lower speed seed scarifier reduced abrasion in cereal caryopses and replacing the single-speed motor with a dual one-third and one-sixth horsepower motor has advantages (Liu, 2007). Although showy ticktrefoil seed can be successfully scarified (no loss of FGP, increased germination rate, and increased uniformity compared with the control) with 60-grit sandpaper by a hand scarification technique, we determined that a scarifier damaged showy ticktrefoil seed. Germination and vigor benefits were obtained for Illinois bundleflower when the scarifier was used, which resulted in increased FGP at multiple temperatures, decreased $\mathrm{G}_{50}$, decreased $\mathrm{G}_{10-90}$, and increased FEP compared with using non-scarified seed.

\section{Literature Cited}

AOSA. 2007a. Suggested purity and/or germination testing methods for species without Association of Official Seed Analysts Rules testing procedures. Assn. of Offic. Seed Analysts. 20 Jan. 2010. <http://www.aosaseed.com>.

AOSA. 2007b. Rules for testing seeds. Assn. of Offic. Seed Analysts, Inc., Stillwater, OK.

Baskin, C.C. 1977. Vigor test methods-Accelerated aging. The Nwsl. of the Assn. of Offic. Seed Analysts 51:42-52.

Baskin, C.C. 2003. Breaking physical dormancy in seeds: Focusing on the lens. New Phytol. 158: 229-232.

Beran, D.D., R.A. Masters, and R.E. Gaussoin. 1999. Grassland legume establishment with imazethapyr and imazapic. Agron. J. 91:592-596.
Beran, D.D., R.A. Masters, R.E. Gaussoin, and F. Rivas-Pantoja. 2000. Establishment of big bluestem and Illinois bundleflower mixtures with imazapic and imazethapyr. Agron. J. 92: 460-465.

Call, C.A. 1985. Storage life of Illinois bundleflower and western indigo seed. J. Range Manage. 38:500-503.

Copeland, L.O. and M.B. McDonald. 2001. Principles of seed science and technology. 4th Ed. Kluwer Academic Publishers, Boston, MA.

Dovel, R.L., M.A. Hussey, and E.C. Holt. 1990. Establishment and survival of Illinois bundleflower interseeded into an established kleingrass pasture. J. Range Manage. 43:153-156.

Ferguson, J.M. 1993. AOSA perspective of seed vigor testing. J. Seed Technol. 17:101-104.

Fulbright, T.E. and K.S. Flenniken. 1987. Temperature and scarification effects on germination of prostrate bundleflower seeds. J. Range Manage. 40:170-173.

Gomez, K.A. and A.A. Gomez. 1984. Statistical procedures for agricultural research. 2nd Ed. Wiley, New York, NY.

Hampton, J.G. and D.M. TeKrony. 1995. Handbook of vigor test methods. 3rd Ed. Intl. Seed Testing Assn., Zurich, Switzerland.

Hartmann, H.T., D.E. Kester, F.T. Davies, Jr., and R.L. Geneve. 2002. Plant propagation principles and practices. 7th Ed. Prentice Hall, Upper Saddle River, NJ.

Hicks, L.S., R.H. Lockerman, L.E. Wiesner, and R.D. Hall. 1989. Reducing physiological imposed seedcoat dormancy of Ruby Valley pointvetch. Appl. Agr. Res. 4:240-242.

ISTA. 2010. International rules for seed testing. Intl. Seed Testing Assn., Bassersdorf, Switzerland.

Jin, Q., L. Duan, J. Li, X. Dong, X. Tian, B. Wang, and Z. Li. 2006. Scarification damages by sulfuric acid and their effects on vigour, germination and emergence of Glycyrrhiza uralensis Fisch seeds. Seed Sci. Technol. 34:227-231.

Kelly, K.M., J. Van Staden, and W.E. Bell. 1992. Seed coat structure and dormancy. Plant Growth Regulat. 11:201-209.

Latting, J. 1961. The biology of Desmanthus illinoensis. Ecology 42:487-493.
Liu, K. 2007. Laboratory methods to remove surface layers from cereal grains using a seed scarifier and comparison with a barley pearler. Cereal Chem. 84:407-414.

Liu, K. 2008. Measurement of wheat hardness by seed scarifier and barley pearler and comparison with a single-kernal characterization system. Cereal Chem. 85:165-173.

Mohamed-Yasseen, Y., S.A. Barringer, W.E. Splittstoesser, and S. Costanza. 1994. The role of seed coats in seed viability. Bot. Rev. 60: 426-439.

Olszewski, M.W., W.G. Pill, D.A. Scheiblin, and K.J. Czymmek. 2009. Use of confocal microscopy to relate germination vigour to embryo morphology of dormant and non-dormant purpletop (Tridens flavus). Seed Sci. Technol. 37: 52-58.

Piotto, B. 1995. Influence of scarification and prechilling on the germination of seeds of Pistacia lentiscus. Seed Sci. Technol. 23:659-663.

Posler, G.L., A.W. Lenssen, and G.L. Fine. 1993. Forage yield, quality, compatibility, and persistence of warm-season grass-legume mixtures. Agron. J. 85:554-560.

Powell, A.A. and S. Matthews. 1978. The damaging effect of water on dry pea embryos during imbibition. J. Expt. Bot. 29:1215-1229.

Powell, A.A. and S. Matthews. 1979. The influence of testa condition on the imbibitions and vigour of pea seeds. J. Expt. Bot. 30:193-197.

Rolston, M.P. 1978. Water impermeable seed dormancy. Bot. Rev. 44:365-396.

Susko, D. 2008. Seed germination for breaking dormancy in showy ticktrefoil (Desmodium canadense). 35th Annu. Natural Areas Conf., Nashville, TN, 14-17 Oct. (abstr.).

USDA, NRCS. 2010a. The PLANTS database. National Plant Data Center, Baton Rouge, LA. 24 Feb. 2010. <http://plants.usda.gov>.

USDA, NRCS. 2010b. 'Sabine' Illinois bundleflower (Desmanthus illinoensis). 17 Feb. 2010. $<$ http://plant-materials.nrcs.usda.gov/news/ features/great_am_plant/sabine.html>.

Wang, Y.R., L. Yu, Z.B. Nan, and Y.L. Liu. 2004. Vigor tests used to rank seed lot quality and predict field emergence in four forage species. Crop Sci. 44:535-541. 